\title{
HUBUNGAN ANTARA MINAT BELAJAR TERHADAP HASIL BELAJAR MATEMATIKA SISWA SDN 3 JATIMULYO
}

\author{
Nureva, Susi Mariyana \\ Nureva.2981@gmail.com, marivana.susi@gmail.com
}

Pendidikan Guru Sekolah Dasar, STKIP Al Islam Tunas Bangsa Bandar Lampung, Indonesia

\begin{abstract}
One factor that influences learning outcomes is interest. In learning activities, if students have an interest in learning, they will feel that learning is very important so they try to focus their attention on things related to learning activities and are happy to do it without coercion from anyone. This research aims to determine the correlation of interest in learning with mathematics learning outcomes of students at Elementary School 3 Jatimulyo, Jatiagung District, South Lampung Regency. This research uses quantitative methods and the type of correlation research. The population of this study was all fourth grade students of Elementary School 3 Jatimulyo. The sample of this study was 69 students. Data collection techniques using questionnaires and documentation. Data analysis uses the product moment correlation formula. The results of this study indicate there is a relationship between learning interest with learning outcomes in mathematics. These results are based on statistical calculations that show a calculation of 0.918> rtable 0.235. The results of the hypothesis analysis can be concluded that there is a positive correlation between learning interest and mathematics learning outcomes of fourth grade students of Elementary School 3 Jatimulyo Odd Semester Academic Year 2018/2019 by judging from the count criteria> rtable.
\end{abstract}

Keywords: interest, result learning, mathematics

\section{ABSTRAK}

Salah satu faktor yang mempengaruhi hasil belajar adalah minat. Dalam kegiatan belajar, jika siswa memiliki minat dalam belajar maka ia akan merasa bahwa belajar itu merupakan hal yang sangat penting sehingga ia berusaha memusatkan erhatiannya kepada hal-hal yang berhubungan dengan kegiatan belajar dan dengan senang hati melakukannya tanpa ada paksaan dari siapapun.. Penelitian ini bertujuan untuk mengetahui hubungan minat belajar dengan hasil belajar matematika siswa SD Negeri 3 Jatimulyo Kecamatan Jatiagung Kabupaten Lampung Selatan. Penelitian ini menggunakan metode kuantitatif dan jenis penelitian korelasi. Populasi dari penelitian ini adalah seluruh siswa kelas IV SD Negeri 3 Jatimulyo. Sampel Penelitian ini berjumlah 69 orang siswa. Teknik Pengumpulan data menggunakan angket dan dokumentasi. Analisis data menggunakan rumus korelasi product moment. Hasil penelitian ini menunjukkan ada hubungan antara minat belajar dengan hasil belajar matematika. Hasil ini berdasarkan perhitungan statistik yang menunjukkan $r_{\text {hitung }} 0.918>r_{\text {tabel }} 0.235$. Hasil analisis hipotesis dapat disimpulkan bahwa ada hubungan yang positif antara minat belajar dengan hasil belajar matematika siswa kelas IV SD Negeri 3 Jatimulyo Semester Ganjil Tahun Pelajaran 2018/2019 dengan dilihat dari kriteria $r_{\text {hitung }}>r_{\text {tabel. }}$

Kata Kunci: minat, hasil belajar, matematika

\begin{tabular}{|c|c|c|}
\hline Submitted & Accepted & Published \\
\hline 23 September 2019 & 04 November 2019 & 14 November 2019 \\
\hline
\end{tabular}

\begin{tabular}{|l|c|c|c|}
\hline Citation & $:$ & $\begin{array}{c}\text { Nureva. (2019). Hubungan Antara Minat Belajar Terhadap Hasil Belajar Matematika Siswa SDN } 3 \text { Jatimulyo. Jurnal } \\
\text { PAJAR (Pendidikan dan Pengajaran), 3(6), 1322-1331. DOI : http://dx.doi.org/10.33578/pjr.v3i6.7895. }\end{array}$ \\
\hline
\end{tabular}

\section{PENDAHULUAN}

Pendidikan adalah proses meningkatkan kualitas manusia baik dari segi pengetahuan, sikap, dan keterampilan dengan mengikuti prosedur tertentu agar dapat bermanfaat bagi dirinya, keluarga, masyarakat, bangsa, dan negara. Jadi pendidikan tidak hanya mengembangkan kemampuan intelektual saja namun juga bagaimana mengimplementasikannya dalam kehidupan bermasyarakat dengan menanamkan nilai-nilai moral. Pendidikan merupakan proses interaksi antara peserta didik dan tenaga pendidik dalam kegiatan pembelajaran (Fauzia, 2018).

Setiap orang tua yang menyekolahkan anaknya menginginkan anaknya meraih nilai yang baik. Namun untuk mencapai hal itu bukanlah suatu hal yang mudah. Hal itu dikarenakan keberhasilan belajar sangat dipengaruhi oleh banyak faktor, salah satunya adalah minat anak dalam belajar. Minat memiliki 
peranan yang sangat penting dalam kehidupan siswa dan mempunyai dampak yang besar terhadap sikap dan perilaku. Siswa yang berminat terhadap kegiatan pembelajaran akan berusaha lebih keras dibandingkan siswa yang kurang berminat dalam belajar. Dalam belajar diperlukan suatu pemusatan perhatian agar apa yang dipelajari dapat dipahami. Dalam meningkatkan minat belajar siswa, proses pembelajaran dapat dilakukan dalam bentuk kegiatan, siswa bekerja dan mengalami apa yang ada di lingkungan secara individu maupun berkelompok.

Menurut Djamarah (2011: 12) belajar adalah suatu kata yang sudah akrab dengan semua lapisan masyarakat. Bagi para pelajar atau mahasiswa kata "belajar" merupakan kata yang tidak asing, bahkan sudah merupakan bagian yang tidak terpisahkan dari semua kegiatan mereka dalam menuntut ilmu di lembaga pendidikan formal. Kegiatan belajar mereka lakukan setiap waktu sesuai dengan keinginan.

Minat belajar dalam diri siswa harus dipupuk secara terus menerus sehingga akan semakin meningkat di dalam diri siswa. Namun, seiring dengan kemajuan teknologi yang semakin pesat dapat mengakibatkan dampak buruk pada minat belajar siswa. Banyak faktor yang dapat menurunkan minat belajar dalam diri siswa seperti, banyaknya jenis hiburan, game, dan tayangan TV yang dapat mengalihkan perhatian siswa dari buku pelajaran. Dengan minat belajar yang tinggi siswa dapat memperoleh pengetahuan dan wawasan serta hasil belajar yang baik. Dalam pembelajaran guru harus melihat kondisi siswa, karena kondisi siswa sangat penting untuk diperhatikan. Kondisi siswa yang sangat penting adalah bagaimana minatnya dalam mata pelajaran. Siswa yang berminat akan lebih perhatian dan akan lebih ingin tahu terhadap mata pelajaran yang dipelajarinya.

Pengembangan minat dan kebiasaan belajar matematika yang baik perlu ditumbuhkan dalam diri siswa sedini mungkin. Guru mempunyai peranan yang sangat penting dalam usaha meningkatkan minat belajar siswa. Minat belajar sangat besar pengaruhnya terhadap hasil belajar, karena apabila bahan pelajaran yang dipelajari tidak sesuai dengan minat, siswa tidak akan belajar dengan baik sebab tidak menarik baginya. Siswa akan malas belajar dan tidak akan mendapatkan kepuasan dari pelajaran itu. Bahan pelajaran yang menarik minat siswa, lebih mudah dipelajari sehingga dapat meningkatkan hasil belajar.

Pembelajaran merupakan interaksi antara guru dengan siswa. Pembelajaran yang baik seharusnya dapat menumbuhkan minat belajar pada diri siswa agar tingkah laku mereka berubah. Perubahan yang dimaksud yaitu perubahan aspek-aspek tingkah laku, seperti pengetahuan, sikap dan keterampilan. Begitu juga dalam pembelajaran matematika yang menekankan pada perubahan aspek-aspek di atas. Tapi pada kenyataannya banyak guru dalam mengajar pelajaran matematika tidak mengikutsertakan keaktifan siswa baik secara fisik maupun mentalnya, dengan pengertian bahwa guru tidak melibatkan siswanya secara aktif.

Pembelajaran sebaiknya bukan hanya pemberian informasi dari guru kepada siswa, tanpa mengembangkan gagasan kreatif siswa, melainkan melalui komunikasi timbal balik antara guru dengan siswa, siswa dapat terlibat aktif dalam belajar baik mental, intelektual, emosional maupun fisik agar mampu mencari dan menemukan pengetahuan, sikap dan keterampilan. Berdasarkan hasil observasi awal di SDN 3 Jatimulyo pada kelas IV sebagai lokasi penelitian diperoleh permasalahan pembelajaran matematika yang dialami oleh siswa antara lain: (1) siswa hanya mendengarkan apa yang dijelaskan guru (2) siswa tidak memperhatikan saat guru menjelaskan pelajaran (3) siswa bermain saat diskusi kelompok (4) guru yang tidak bisa menciptakan ruang kelas yang kondusif, dan (5) hasil belajar siswa rendah. Dari hasil wawancara dengan wali kelas IV sebagian besar hasil belajar siswa rendah karena kurang pahamnya siswa dalam memahami materi pelajaran serta kurangnya minat belajar siswa dalam mengikuti pelajaran. Salah satu penyebab rendahnya nilai hasil belajar disebabkan oleh rendahnya minat belajar siswa terhadap mata pelajaran tersebut. Rendahnya hasil belajar disebabkan oleh banyak faktor tetapi dalam penelitian ini peneliti hanya menggolongkan ke 
dalam dua faktor saja yaitu faktor internal dan eksternal.

Proses belajar mengajar dan hasil belajar siswa sebagian besar ditentukan oleh peranan dan kompetensi guru. Guru yang kompeten akan lebih mampu menciptakan lingkungan belajar yang efektif dan akan lebih mampu mengelola kelasnya dan guru dituntut untuk terus membangkitkan minat belajar siswa sehingga hasil belajar siswa berada pada tingkat optimal. Dengan minat yang tinggi akan melahirkan siswa-siswa yang berprestasi dan meningkatkan hasil belajar terutama pada mata pelajaran matematika, sehingga akan berpengaruh pada hasil belajar yang diraih siswa. Mengupayakan munculnya siswa yang memiliki hasil belajar yang baik sungguh memerlukan kerja keras dan perhatian yang total, terutama dari pihak sekolah.

Penelitian ini didukung juga dari jurnal yang dihasilkan oleh beberapa peneliti, diantaranya Lestari (2013, 115-125) yang berjudul pengaruh waktu belajar dan minat belajar terhadap hasil belajar matematika. Hasil penelitian menunjukkan bahwa terdapat pengaruh yang signifikan antara waktu belajar dengan hasil belajar dengan nilai sig 0.038 dan terdapat pengaruh signifikan antara minat belajar dengan hasil belajar dengan nilai sig 0.00. selain itu, penelitian yang dilakukan oleh Wardiana, dkk (2014) yang berjudul "Hubungan antara Adversity Quotient (Aq) dan minat belajar dengan prestasi belajar matematika pada siswa kelas V SD di Kelurahan Pedungan". Hasil penelitian menunjukkan: (1) terdapat hubungan yang positif signifikan antara AQ dan prestasi belajar matematika dengan $\mathrm{rx} 1=0,525$ dan koefisien determinasi sebesar $27,56 \%$, (2)

\section{KAJIAN TEORETIS \\ Hasil Belajar}

Menurut Nawawi dalam K. Brahim, (Susanto, 2013:5) mengatakan bahwa hasil belajar dapat diartikan sebagai tingkat keberhasilan siswa dalam mempelajari materi pelajaran di sekolah yang dinyatakan dalam skor yang diperoleh dari hasil tes mengenal sejumlah materi pelajaran tertentu. Sudjana (2009:22) berpendapat bahwa, hasil belajar adalah terdapat hubungan yang positif signifikan antara minat belajar dan prestasi belajar matematika dengan $\mathrm{rx} 2=0,575$ dan koefisien determinasi sebesar $33,06 \%$, (3) terdapat hubungan yang positif signifikan secara bersama-sama antara AQ dan minat belajar dengan prestasi belajar matematika dengan rx $1 x 2 y=0,639$ dan koefisien determinasinya sebesar $40,83 \%$.

Berdasarkan latar belakang di atas, peneliti tertarik untuk melaksanakan penelitian dengan judul hubungan antara minat belajar dengan hasil belajar matematika siswa kelas IV SDN 3 Jatimulyo.

Penelitian ini bertujuan untuk mengetahui hubungan minat belajar dengan hasil belajar matematika siswa SD Negeri 3 Jatimulyo Kecamatan Jatiagung Kabupaten Lampung Selatan. Manfaat penelitian ini terbagi menjadi 2 (dua) bagian, yaitu manfaat teoritis dan manfaat praktis.

1. Manfaat Teoritis

Penelitian ini secara teoritis diharapkan dapat memberikan konstribusi bagi dunia pendidikan, untuk menambah dan memperkaya pengetahuan pengkajian yang berhubungan dengan hubungan minat belajar terhadap hasil belajar siswa.

2. Manfaat Praktis

Sebagai bahan informasi dan pertimbangan guru dalam upaya meningkatkan hasil belajar siswa dengan memperhatikan minat siswa. Memberikan sumbangan pemikiran dan perbaikan dalam penanganan masalah minat belajar terhadap hasil belajar siswa di tahun yang akan datang.

kemampuan-kemampuan yang dimiliki siswa setelah ia menerima pengalaman belajarnya. Secara sederhana, yang dimaksud dengan hasil belajar siswa adalah kemampuan yang diperoleh anak-anak setelah melalui kegiatan belajar.

Menurut aliran behavioristik menganggap bahwa belajar merupakan perubahan perilaku yang dapat dilakukan melalui manipulasi lingkungan yang mempengaruhi peserta didik. 
Aliran ini menekankan pada hasil proses belajar, dimana seorang dianggap telah belajar jika dia mampu menunjukan perubahan tingkah laku (Sani, 2014: 3).

Menurut Sardiman (2014) salah satu pertanda bahwa seseorang telah belajar adalah adanya perubahan tingkah laku dalam dirinya. Perubahan tingkah laku tersebut menyangkut baik perubahan yang bersifat pengetahuan (kognitif) dan keterampilan (psikomotor) maupun yang menyangkut nilai dan sikap (afektif). Berdasarkan pendapat-pendapat di atas dapat disimpulkan bahwa hasil belajar yaitu perubahan perilaku ataupun peningkatan pemahaman pengetahuan dan pengalaman sebagai dampak adanya proses pembelajaran. Dampak adanya proses pembelajaran tersebut dapat diukur baik melalui tes perilaku, tes kemampuan kognitif, maupun tes psikomotorik (Suwastini, 2019).

Belajar merupakan suatu proses kegiatan yang dilakukan oleh seseorang yang menghasilkan suatu perubahan tingkah laku yang baru sebagai hasil interaksi dengan lingkungannya. Dengan kata lain, bahwa belajar adalah "perubahan" dalam diri individu yang belajar. Perubahan yang dimaksud adalah perubahan-perubahan yang dikehendaki oleh pengertian belajar itu sendiri. Karena belajarmerupakan suatu proses usaha, maka didalamnya terdapat tahapan-tahapan yang harus dilalui untuk sampai kepada hasil belajar itu sendiri (Islamiyah, 2019).

\section{Minat Belajar}

Menurut Bloom (Susanto, 2013:59), minat adalah apa yang disebutnya sebagai subjectrelated affect, yang didalamnya termasuk minat dan sikap terhadap materi pelajaran. Namun ternyata sulit menemukan pembatas yang jelas antara minat dan sikap terhadap materi pelajaran, yang tampak adalah sebuah kontinum yang terentang dari pandangan-pandangan negatif atau afek (affect) negatif terhadap pelajaran. Ini dapat diukur dengan menanyakan kepada seseorang apakah ia mempelajari itu, apa yang disukai atau tidak disukainya mengenai pelajaran dan berbagi pendekatan dengan menggunakan kuesioner yang berupaya meningkatkan berbagai pendapat, pandangan, dan prefrensi yang mungkin menunjukan suatu afek positif atau negatif terhadap pelajaran.

Minat pada dasarnya adalah timbulnya keinginan dan kemauan seseorang yang menyatu sehingga gigih dan semangat melakukan sesuatu. Rasa lebih suka dan ketertarikan akan direspon oleh pikiran seseorang untuk melakukan aktivitas sesuai jenis kesukaan tanpa adanya pengaruh atau paksaan, karena dilandasi kesenangan. Suatu minat dapat diekspresikan melalui suatu pernyataan yang menunjukkan bahwa siswa lebih menyukai suatu hal daripada hal lainnya. Siswa yang memiliki minat terhadap subjek tertentu cenderung untuk memberikan perhatian yang lebih besar terhadap subjek tersebut (Pratiwi, 2015).

Minat menurut Slameto (2015:180) adalah suatu rasa lebih suka dan rasa ketertarikan pada suatu hal atau aktivitas, tanpa ada yang menyuruh. Minat akan timbul apabila mendapat rangsangan dari luar. Sehingga kecenderungan untuk merasa tertarik pada suatu bidang bersifat menetap dan merasakan perasaan yang senang apabila ia terlibat aktif didalamnya. Sedangkan perasaan senang ini timbul dari lingkungan atau berasal dari objek yang menarik.

Minat merupakan salah satu faktor yang dapat mempengaruhi belajar dan hasilnya maka minat dapat mempengaruhi kualitas pencapaian hasil belajar siswa dalam bidang-bidang tertentu. Minat belajar yang besar cenderung menghasilkan prestasi yang tinggi, sebaliknya minat belajar yang kurang akan menghasilkan prestasi yang rendah. Maka apabila seorang siswa mempunyai minat yang besar terhadap suatu bidang studi ia akan memusatkan perhatian lebih banyak dari temannya, kemudian karena pemusatan perhatian yang intensif terhadap materi itulah yang memungkinkan siswa tadi untuk belajar lebih giat, dan akhirnya mencapai prestasi yang tinggi dalam bidang studi tersebut. Demikian pula halnya dengan minat siswa terhadap pelajaran matematika, apabila seorang siswa mempunyai minat yang besar terhadap pelajaran matematika maka siswa tersebut akan memusatkan perhatiannya terhadap pelajaran matematika dan lebih giat dalam mempelajari pelajaran ini dan hasilnya pun akan memuaskan. 
Melihat betapa pentingnya pencapaian nilai hasil belajar matematika siswa dalam pembelajaran, maka rendahnya hasil belajar matematika merupakan permasalahan yang harus diperhatikan oleh guru. Permasalahan tersebut dapat disebabkan oleh beberapa faktor, salah satunya guru jarang menggunakan media, karena media dapat membantu dalam kegiatan pembelajaran dan membuat pelajaran matematika

\section{METODE PENELITIAN}

Pendekatan yang digunakan dalam penelitian ini adalah pendekatan kuantitatif, karena data berupa angka-angka dan dianalisis menggunakan statistik. Tujuan peneliti menggunakan pendekatan kuantitatif karena peneliti menghilangkan subjektifitas dalam penelitian. Jenis penelitian yang digunakan dalam penelitian ini adalah korelasi. Penelitian ini dilaksanakan di SD Negeri 3 Jatimulyo, Kabupaten Lampung Selatan, pada semester ganjil tahun pelajaran 2018/2019. Tahap-tahap atau langkah-langkah penelitian ini adalah: 1) memilih subjek penelitian yaitu guru kelas dan siswa kelas IV SD Negeri 3 Jatimulyo dan subjek uji coba instrumen kuesioner (angket) yaitu siswa yang merupakan bagian dari subjek penelitian namun tidak termasuk dalam sampel penelitian; 2) menyusun kisi-kisi dan instrumen pengumpulan data yang berupa angket; 3) menguji cobakan instrumen pengumpul data pada subjek uji coba instrumen; 4) menganalisisdata dari hasil uji coba instrumen untuk mengetahui apakahinstrumen yangdisusun telah valid dan

\section{HASIL DAN PEMBAHASAN}

Dalam penelitian ini terdapat dua variabel yaitu variabel bebas dan variabel terikat. Variabel bebas (X) yaitu minat belajar dan veriabel terikat (Y) yaitu hasil belajar siswa kelas IV SD Negeri 3 Jatimulyo Kecamatan Jatiagung Kabupaten Lampung Selatan terutama pada mata pelajaran matematika.

Data minat belajar dapat diperoleh melalui angket yang terdiri dari 40 pernyataan yang dijawab siswa yang berisi tentang indikatorindikator variabel $\mathrm{X}$ tentang minat belajar. Dari menjadi tidak menarik lagi bagi siswa. Hal ini mungkin menjadi penyebab kurangnya minat dalam pelajaran matematika. Oleh karena itu, minat merupakan dasar yang penting dalam keberhasilan proses pembelajaran. Jika siswa merasa senang dalam belajar, maka ia akan dengan cepat mengerti dan memahami materi yang diberikan guru.

reliabel; 5) melaksanakan penelitian dengan membagikan instrumen angket kepada sampel penelitian. Sedangkan untuk mengetahui hasil belajar matematika, dilakukan studi dokumentasi yang dilihat pada dokumen hasil nilai mid semester ganjil dari guru kelas IV SD Negeri 3 Jatimulyo; 6) menghitung kedua data yang diperoleh untuk mengetahui hubungan antara minat belajar terhadap hasil belajar siswa kelas IV SD Negeri 3 Jatimulyo; dan 7) interpertasi hasil analisis data.

Populasi pada penelitian ini adalah seluruh siswa kelas IV SD Negeri 3 Jatimulyo Lampung Selatan tahun pelajaran 2018/2019. Sampel pada penelitian ini berjumlah 69 siswa. Variabel penelitian pada penelitian ini adalah variabel $\mathrm{X}$ adalah minat belajar, dan variabel $\mathrm{Y}$ pada penelitian ini adalah hasil belajar. Teknik pengumpulan data pada penelitian ini adalah dokumentasi dan angket. Uji instrumen dalam penelitian ini menggunakan korelasi product moment.

40 angket tersebut diuji validitasnya dan hasilnya yang valid yaitu 31 pernyataan. 31 pernyataan tersebut kemudian disebarkan kembali kepada siswa kelas IV SD Negeri 3 Jatimulyo. Penelitian dilakukan menggunakan 69 orang siswa kelas IV SD Negeri 3 Jatimulyo Kecamatan Jatiagung Kabupaten Lampung Selatan. Peneliti membacakan petunjuk dalam pengisian angket. Tugas siswa hanya memberikan tanda cek lis $(\checkmark)$ pada tanda kategori "SL" (Selalu), "SR" (Sering), "KK" (Kadang-Kadang), "TP" (Tidak pernah). 
Untuk pernyataan "SL" apabila positif nilainya 4 dan jika negatif nilainya 1, "SR" apabila pernyataan positif nilainya 3 dan jika negatif nilainya 2, "KK" apabila pernyataan positif nilainya 2 , dan jika pernyataan negatif nilainya 3 ,
"TP" apabila pernyataan positif nilainya 1 dan jika pernyataan negatif nilainya 4 dan waktu pengisian angket selama 30 menit.

Hasil korelasi antara variabel $\mathrm{X}$ dan variabel $\mathrm{Y}$ dapat dilihat pada tabel berikut:

Tabel 1. Hasil Korelasi Antara Variabel X dan Variabel Y

\begin{tabular}{|c|c|c|c|c|c|}
\hline $\begin{array}{c}\text { No. } \\
\text { Siswa }\end{array}$ & $\mathbf{X}$ & $\mathbf{Y}$ & $x^{2}$ & $\mathbf{Y}^{2}$ & XY \\
\hline 1 & 85 & 60 & 7225 & 3600 & 5100 \\
\hline 2 & 74 & 50 & 5476 & 2500 & 3700 \\
\hline 3 & 83 & 60 & 6889 & 3600 & 4980 \\
\hline 4 & 80 & 65 & 6400 & 4225 & 5200 \\
\hline 5 & 105 & 70 & 11025 & 4900 & 7350 \\
\hline 6 & 104 & 75 & 10816 & 5625 & 7800 \\
\hline 7 & 83 & 60 & 6889 & 3600 & 4980 \\
\hline 8 & 111 & 80 & 12321 & 6400 & 8880 \\
\hline 9 & 78 & 60 & 6084 & 3600 & 4680 \\
\hline 10 & 80 & 65 & 6400 & 4225 & 5200 \\
\hline 11 & 109 & 80 & 11881 & 6400 & 8720 \\
\hline 12 & 73 & 50 & 5329 & 2500 & 3650 \\
\hline 13 & 70 & 50 & 4900 & 2500 & 3500 \\
\hline 14 & 81 & 60 & 6561 & 3600 & 4860 \\
\hline 15 & 101 & 70 & 10201 & 4900 & 7070 \\
\hline 16 & 112 & 90 & 12544 & 8100 & 10080 \\
\hline 17 & 112 & 80 & 12544 & 6400 & 8960 \\
\hline 18 & 106 & 70 & 11236 & 4900 & 7420 \\
\hline 19 & 78 & 60 & 6084 & 3600 & 4680 \\
\hline 20 & 78 & 60 & 6084 & 3600 & 4680 \\
\hline 21 & 74 & 50 & 5476 & 2500 & 3700 \\
\hline 22 & 75 & 50 & 5625 & 2500 & 3750 \\
\hline 23 & 93 & 70 & 8649 & 4900 & 6510 \\
\hline 24 & 99 & 70 & 9801 & 4900 & 6930 \\
\hline 25 & 78 & 60 & 6084 & 3600 & 4680 \\
\hline 26 & 76 & 50 & 5776 & 2500 & 3800 \\
\hline 27 & 80 & 60 & 6400 & 3600 & 4800 \\
\hline 28 & 101 & 70 & 10201 & 4900 & 7070 \\
\hline 29 & 114 & 80 & 12996 & 6400 & 9120 \\
\hline 30 & 76 & 60 & 5776 & 3600 & 4560 \\
\hline 31 & 113 & 80 & 12769 & 6400 & 9040 \\
\hline 32 & 98 & 75 & 9604 & 5625 & 7350 \\
\hline 33 & 77 & 65 & 5929 & 4225 & 5005 \\
\hline 34 & 111 & 80 & 12321 & 6400 & 8880 \\
\hline 35 & 76 & 60 & 5776 & 3600 & 4560 \\
\hline 36 & 76 & 60 & 5776 & 3600 & 4560 \\
\hline 37 & 78 & 60 & 6084 & 3600 & 4680 \\
\hline 38 & 100 & 70 & 10000 & 4900 & 7000 \\
\hline
\end{tabular}




\begin{tabular}{|c|c|c|c|c|c|}
\hline $\begin{array}{c}\text { No. } \\
\text { Siswa }\end{array}$ & $\mathbf{X}$ & $\mathbf{Y}$ & $x^{2}$ & $\mathbf{Y}^{2}$ & XY \\
\hline 39 & 112 & 90 & 12544 & 8100 & 10080 \\
\hline 40 & 76 & 60 & 5776 & 3600 & 4560 \\
\hline 41 & 75 & 60 & 5625 & 3600 & 4500 \\
\hline 42 & 92 & 70 & 8464 & 4900 & 6440 \\
\hline 43 & 73 & 50 & 5329 & 2500 & 3650 \\
\hline 44 & 74 & 60 & 5476 & 3600 & 4440 \\
\hline 45 & 76 & 60 & 5776 & 3600 & 4560 \\
\hline 46 & 95 & 70 & 9025 & 4900 & 6650 \\
\hline 47 & 79 & 60 & 6241 & 3600 & 4740 \\
\hline 48 & 110 & 80 & 12100 & 6400 & 8800 \\
\hline 49 & 80 & 60 & 6400 & 3600 & 4800 \\
\hline 50 & 78 & 60 & 6084 & 3600 & 4680 \\
\hline 51 & 75 & 50 & 5625 & 2500 & 3750 \\
\hline 52 & 95 & 75 & 9025 & 5625 & 7125 \\
\hline 53 & 109 & 85 & 11881 & 7225 & 9265 \\
\hline 54 & 75 & 50 & 5625 & 2500 & 3750 \\
\hline 55 & 73 & 55 & 5329 & 3025 & 4015 \\
\hline 56 & 77 & 65 & 5929 & 4225 & 5005 \\
\hline 57 & 77 & 65 & 5929 & 4225 & 5005 \\
\hline 58 & 111 & 80 & 12321 & 6400 & 8880 \\
\hline 59 & 73 & 50 & 5329 & 2500 & 3650 \\
\hline 60 & 74 & 50 & 5476 & 2500 & 3700 \\
\hline 61 & 79 & 60 & 6241 & 3600 & 4740 \\
\hline 62 & 97 & 70 & 9409 & 4900 & 6790 \\
\hline 63 & 111 & 90 & 12321 & 8100 & 9990 \\
\hline 64 & 78 & 60 & 6084 & 3600 & 4680 \\
\hline 65 & 78 & 60 & 6084 & 3600 & 4680 \\
\hline 66 & 100 & 70 & 10000 & 4900 & 7000 \\
\hline 67 & 77 & 50 & 5929 & 2500 & 3850 \\
\hline 68 & 75 & 50 & 5625 & 2500 & 3750 \\
\hline 69 & 78 & 65 & 6084 & 4225 & 5070 \\
\hline Jumlah & 6030 & 4465 & 541018 & 297175 & 400080 \\
\hline$\sum X$ & 6030 & & & & \\
\hline$\sum \mathrm{Y}$ & 4465 & & & & \\
\hline$\sum X^{2}$ & 541018 & & & & \\
\hline$\sum \mathrm{Y}^{2}$ & 297175 & & & & \\
\hline$\left(\sum X\right)^{2}$ & 36360900 & & & & \\
\hline$\left(\sum \mathrm{Y}\right)^{2}$ & 19936225 & & & & \\
\hline$\sum X Y$ & 400080 & & & & \\
\hline $\mathrm{N}$ & 69 & & & & \\
\hline
\end{tabular}

Berdasarkan data di atas, selanjutnya dianalisis dengan menggunakan korelasi product moment: 


$$
\begin{gathered}
\mathrm{r}_{\mathrm{xy}}=\frac{N \cdot \sum \mathrm{XY}-\left(\sum \mathrm{X}\right)\left(\sum \mathrm{Y}\right)}{\sqrt{\left\{N \cdot \sum \mathrm{X}^{2}-\left(\sum \mathrm{X}\right)^{2}\right\}\left\{N \cdot\left(\sum \mathrm{Y}\right)^{2}-\left(\sum \mathrm{Y}\right)^{2}\right\}}} \\
\mathrm{r}_{\mathrm{xy}}==\frac{69.400080-(6030)(4465)}{\sqrt{\left\{69.541018-(6030)^{2}\right\}\left\{69.297175-(4465)^{2}\right\}}} \\
\mathrm{r}_{\mathrm{xy}}=\frac{27605520-26923950}{\sqrt{\{37330242-363609000\}\{20505075-19936225\}}} \\
\mathrm{r}_{\mathrm{xy}}=\frac{681570}{\sqrt{969342.568850}} \\
\mathrm{r}_{\mathrm{xy}}=\frac{681570}{\sqrt{551410196700}} \\
\mathrm{r}_{\mathrm{xy}}=\frac{681570}{742570} \\
\mathrm{r}_{\mathrm{xy}}=0.918
\end{gathered}
$$

Analisis data yang dilakukan oleh peneliti dapat dilihat $r_{\text {hitung }} 0.918>r_{\text {tabel }} 0.235$. Setelah diketahui koefisien korelasi, analisis dapat dilanjutkan dengan menghitung koefisien determinan. Koefisien determinan dilakukan untuk mengetahui seberapa besar hubungan antara minat belajar terhadap hasil belajar matematika. Selanjutnya koefisien determinan minat belajar terhadap hasil belajar dapat diperoleh dengan rumus $\mathrm{KD}=\mathrm{r} 2 \times 100 \%=$ $(0,918) 2 \times 100 \%=84,27 \%$. Hasil nilai koefisien determinan dalam penelitian ini adalah $84,27 \%$ dengan demikian dapat diartikan bahwa minat belajar dapat meningkatkan hasil belajar matematika sebesar $84,27 \%$.

Berdasarkan hasil analisis data, diperoleh koefisien korelasi positif menunjukkan hubungan antara minat belajar dengan hasil belajar matematika positif. Artinya meningkatnya minat belajar pada diri siswa akan membawa kenaikan pada hasil belajar siswa dan sebaliknya ketika minat belajar rendah maka hasil belajar cenderung rendah.

Minat belajar memiliki pengaruh yang besar terhadap hasil belajar, penelitian ini membuktikan bahwa minat belajar dengan hasil belajar berhubungan. Minat belajar siswa yang rendah mengakibatkan siswa mengalami kesulitan dalam belajar. Hal ini disebabkan karena siswa tidak tertarik pada kegiatan yang berkenaan dengan proses belajar siswa juga tidak mengetahui pentingnya memperhatikan dan menguasai mata pelajaran yang disampaikan oleh guru. Siswa yang sudah tidak tertarik dan tidak memahami tujuan mengapa ia belajar akan cenderung tidak memiliki keinginan untuk menguasai dan terlibat dalam kegiatan belajar itu. Hal ini membuat siswa menjadi sulit memahami materi yang disampaikan guru. Hendaknya sebagai guru menciptakan suasana yang ramah, antusias, bersahabat dan sebagainya. Sebab dapat mendorong tingkah dan kesenangan dalam mengerjakan tugas sehingga minat siswa akan timbul.

Hasil penelitian ini diperkuat oleh beberapa penelitian lain, diantara penelitian yang dilakukan oleh Febriyanti (2014) yang berjudul peran minat dan interaksi siswa dengan guru dalam meningkatkan hasil belajar matematika. Hasil penelitian menunjukkan bahwa terdapat pengaruh yang signifikan antara interaksi siswa dan guru dan minat belajar terhadap hasil belajar matematika, dengan koefisien korelasi 0.87 dan koefisien determinasi sebesar 76,8\%. Selain itu, penelitian yang dilakukan oleh Kpolovie, dkk (2014) yang berjudul academic achievement prediction: role of interest in learning and attitude towards school. Hasil penelitian menunjukkan bahwa peningkatan minat belajar dan sikap siswa dalam sekolah dapat memberikan kontribusi dalam meningkatkan kemampuan secara akademis. Selanjutnya penelitian yang dilakukan oleh Nisa (2015) yang berjudul pengaruh perhatian orang tua dan minat belajar siswa terhadap prestasi belajar ilmu pengetahuan sosial. Hasil penelitian ini menunjukkan bahwa terdapat pengaruh yang signifikan antara perhatian orang tua dan minat belajar siswa 
terhadap prestasi belajar ilmu pengetahuan sosial. Penelitian lain dilakukan oleh Lee, dkk (2011) yang berjudul the influences of interest in learning and learning hours on learning outcomes of vocational college students in Taiwan. Hasil atau temuan dari penelitian Lee menunjukkan bahwa mahasiswa kejuruan di Taiwan yang memiliki sikap puas terhadap gurunya, baik minat dan jam belajar memiliki pengaruh yang positif dan signifikan terhadap hasil belajar.

Djamarah (2011:191) minat pada dasarnya adalah penerimaan akan suatu hubungan

\section{SIMPULAN DAN REKOMENDASI}

Berdasarkan hasil penelitian dan pembahasan, dengan adanya koefisien korelasi antara minat belajar terhadap hasil belajar matematika, maka dapat disimpulkan bahwa terdapat hubungan yang positif antara minat belajar dengan hasil belajar matematika siswa kelas IV SD Negeri 3 Jatimulyo Kecamatan Jatiagung Lampung Selatan pada semester ganjil.

Berdasarkan hasil penelitian ini, yang menunjukkan minat belajar memiliki hubungan yang positif terhadap hasil belajar matematika maka saran penulis sebagai berikut:

1. Bagi guru

Guru harus lebih mengetahui faktor internal dan faktor eksternal yang berada dalam diri siswa agar guru dapat mengetahui perkembangan minat belajar siswa selama dalam proses kegiatan belajar mengajar.

Sebaiknya guru memperhatikan dan selalu membangkitkan minat belajar siswa agar

\section{DAFTAR PUSTAKA}

Djamarah, S.B. (2011). Psikologi Belajar. Jakarta: Rineka Cipta

Fauzia, H.A. (2018). Penerapan Model Pembelajaran Problem Based Learning Untuk Meningkatkan Hasil Belajar Matematika SD. Primary: Jurnal Program Studi Pendidikan Guru Sekolah Dasar, 7(1), 12-22.

Febriyanti, C \& Seruni. (2014). Peran Minat dan Interaksi Siswa dengan Guru dalam antara diri sendiri dengan sesuatu di luar diri. semakin kuat dan dekat hubungan tersebut, semakin besar minat yang ada. Hal ini menjadi dasar baik bagi guru, orang tua serta lingkungan untuk dapat mendukung tumbuhnya minat pada diri siswa untuk belajar. Berdasarkan hasil uji hipotesis peneliti menujukkan pada taraf signifikan $5 \% \quad \mathrm{r}_{\text {hitung }} 0.918>\mathrm{r}_{\text {tabel }}$ 0.235. Dari analisis tersebut dapat disimpulkan bahwa ada hubungan antara minat belajar dengan hasil belajar matematika siswa kelas IV SD Negeri 3 Jatimulyo dengan dilihat dari kriteria $r_{\text {hitung }}>r_{\text {tabel }}$.

pelaksanaan pembelajaran berjalan dengan baik sehingga hasil belajar siswa meningkat, khususnya pada mata pelajaran matematika.

Guru harus memberikan pembelajaran yang menarik dan kreatif sehingga siswa berminat dalam mengikuti kegiatan belajar mengajar dengan baik.

2. Bagi kepala sekolah

Sebaiknya kepala sekolah selalu menghimbau guru untuk meningkatkan minat belajar siswa guna meningkatkan prestasi belajar siswa, khususnya pada mata pelajaran matematika.

3. Bagi peneliti

Peneliti dapat mengembangkan instrument yang dapat mengukur minat belajar secara lebih tepat untuk mengurangi keterbatasan pada penelitian ini. Selain itu peneliti dapat memperluas populasi agar dapat digeneralisasikan pada subjek yang lebih luas.

Meningkatkan Hasil Belajar Matematika. Jurnal Formatif, 4(3), 245- 254.

Islamiyah. (2019). Penerapan Model Pembelajaran Inkuiri Terbimbing untuk Meningkatkan Hasil Belajar Agama Islam Kelas VB SD Negeri 37 Pekanbaru. Jurnal PAJAR (Pendidikan dan Pengajaran), 3(4), 686-696. DOI:http://dx.doi.org /10.33578/ pjr.v3i4.7450. 
Kpolovie, PJ. (2014). Academic Achiment Prediction: Role of Interest in Learning and Attitude toward School. International Journal of Humanities Social Sciences and Education (IJHSSE), 1(11), 73-100.

Lee, Y. (2011). The Influences of Interest in Learning and Learning Hours on Learning Outcomes of Vocational College Students in Taiwan: using a Teacher's Instructional Attitude as the Moderator. Global Journal of Engineering Education (GJEE), 13(3),, 140- 153.

Lestari, I. (2013). Pengaruh Waktu Belajar dan Minat Belajar terhadap Hasil Belajar Matematika. Jurnal Formatif, 3(2), 115125.

Nisa, A. (2015). Pengaruh Perhatian Orang Tua dan Minat Belajar Siswa terhadap Prestasi Belajar IPS. Jurnal Ilmiah Kependidikan, 2(1), 1- 9.

Pratiwi, N.K. (2015). Pengaruh Tingkat Pendidikan, Perhatian Orang Tua, dan Minat Belajar Siswa Terhadap Prestasi Belajar Bahasa Indonesia Siswa SMK Kesehatan di Kota Tangerang. Jurnal Pujangga, 1(5).

Sani, B. (2014). Strategi Pembelajaran di dalam Kelas. Bandung: Alfabeta.

Sardiman. (2014). Interaksi dan Motivasi Belajar Mengajar. Jakarta: Raja Grafindo Persada.

Slameto. (2015). Belajar dan Faktor-Faktor yang Mempengaruhi. Jakarta: Rineka Cipta.

Susanto, A. (2013). Teori Belajar Pembelajaran di Sekolah Dasar. Jakarta: Prenadamedia Group.

Sudjana, N. (2009). Penilaian Hasil Proses Belajar Mengajar. Bandung : Remaja Rosdakarya.

Suwartini, S., \& Ferryka, P.Z. (2019). Peningkatan Hasil Belajar Tema CitaCitaku Berbasis Constektual Teaching Learning (CTL) di Kelas IV SD Negeri 1 Gergunung. Jurnal PAJAR (Pendidikan dan Pengajaran), 3(5), 1188-1195. DOI: http://dx.doi.org/10.33578/pjr.v3i5.7851.

Wardiana, I.P.A. (2014). Hubungan antara Adversity Quotient (AQ) dan Minat Belajar dengan Prestasi Belajar Matematika pada Siswa Kelas V SD di Kelurahan Pedungan. Jurnal Mimbar PGSD Universitas Pendidikan Ganesha, 2(1), 111. 